of relocation planning as a climate change response.

\section{Carol Farbotko (D) $1 \otimes$, Olivia Dun (D)2 Fanny Thornton (D) ${ }^{3}$, Karen E. McNamara (D) and Celia McMichael (D) 5}

${ }^{1}$ School of Social Sciences, University of the Sunshine Coast, Sippy Downs, Queensland, Australia. ${ }^{2}$ School of Geography, University of Melbourne, Melbourne, Victoria, Australia. ${ }^{3}$ Canberra Law School, University of Canberra, Bruce, Australian Capital Territory, Australia. ${ }^{4}$ School of Earth and Environmental Sciences, The University of Queensland, Brisbane, Queensland, Australia. ${ }^{5}$ School of Geography, University of Melbourne, Melbourne, Victoria, Australia.

$凶_{e-m a i l: c f a r b o t k @ u s c . e d u . a u}$
Published online: 13 July 2020

$\neg$ https://doi.org/10.1038/s41558-020-0829-6

References

1. Ferris, E. \& Weerasinghe, S. JMHS (in the press)

2. Hino, M., Field, C. B. \& Mach, K. J. Nat. Clim. Change 7, 364-370 (2017)

3. Birk, T. in Climate Change and Human Mobility: Global Challenges to the Social Sciences (eds Hastrup, K. \& Olwig, K. F.) 81-109 (Cambridge Univ. Press, 2012).

4. Bronen, R. in Resilience: The Science of Adaptation to Climate Change (eds Zommers, Z. \& Alverson, K.) 117-126 (Elsevier, 2018)

5. Lindegaard, L. S. Clim. Dev. (in the press)

6. Piggott-McKellar, A. E., McNamara, K. E., Nunn, P. D. \& Sekinini, S. T. Soc. Sci. 8, 133 (2019).

7. McMichael, C., Katonivualiku, M. \& Powell, T. Geogr. J. 185, 325-337 (2019).

8. Bronen, R. \& Chapin, F. S. Proc. Natl Acad. Sci. USA 110 9320-9325 (2013).

9. Bordner, A. S., Ferguson, C. E. \& Ortolano, L. Glob. Environ Change 61, 102054 (2020)
10. Farbotko, C. \& McMichael, C. Asia Pac. Viewp. 60 , 148-162 (2019)

11. Perumal, N. Isl. Stud. J. 13, 45-64 (2018).

2. Arnall, A. Clim. Dev. 11, 253-263 (2019).

13. Rogers, S. \& Wilmsen, B. Prog. Hum. Geogr. 44, 256-275 (2020).

14. Birkmann, J. et al. Nat. Hazards 67, 193-211 (2013).

15. Rogers, S. \& Xue, T. Glob. Environ. Change 35 , 62-69 (2015).

16. Wilmsen, B. \& Webber, M. Geoforum 58, 76-85 (2015)

17. Cernea, M. Water Sci. 1, 89-120 (2008).

18. Morel, M., Stavropoulou, M. \& Durieux, J.-F. Forced Migr. Rev. 41, 5-7 (2012).

19. Kothari, U. Geogr. J. 180, 130-140 (2014).

20. International Covenant on Civil and Political Rights (United Nations, 1966); https://www.ohchr.org/en/professionalinterest/ pages/ccpraspx

1. Zickgraf, C. Soc. Sci. 8, 228 (2019)

22. United Nations Declaration on the Rights of Indigenous Peoples A/RES/61/295 (United Nations General Assembly, 2007); https:// www.un.org/development/desa/indigenouspeoples/wp-content/ uploads/sites/19/2018/11/UNDRIP_E_web.pdf

\title{
The future of coal in a carbon-constrained climate
}

Phasing out coal requires expanding the notion of a 'just transition' and a roadmap that specifies the sequence of coal plant retirement, the appropriate policy instruments as well as ways to include key stakeholders in the process.

\section{Michael Jakob, Jan Christoph Steckel, Frank Jotzo, Benjamin K. Sovacool, Laura Cornelsen, Rohit Chandra, Ottmar Edenhofer, Chris Holden, Andreas Löschel, Ted Nace, Nick Robins, Jens Suedekum and Johannes Urpelainen}

D espite decades of knowledge about its contribution to climate change, coal combustion still accounts for $40 \%$ of global $\mathrm{CO}_{2}$ emissions from energy use. The power sector must stop using coal without carbon capture and storage by approximately 2050 if the Paris Agreement climate goals are to be achieved ${ }^{1}$. This will not be easy. Globally, the coal mining industry alone employs about 8 million people and creates revenues of more than US\$900 billion a year ${ }^{2}$. While growth in coal investments is slowing and COVID-19-induced electricity demand reductions have cut coal-fired electricity output in 2020 , coal use is unlikely to decline substantially in the medium term. Reductions in the USA and Europe are offset by growth in China, India and other Asian countries ${ }^{3,4}$, thus locking in future demand (Fig. 1). African countries may follow next ${ }^{5}$.

Still, the urgency of climate change action demands the world to reduce coal use without carbon capture and storage quickly, and cease it over coming decades ${ }^{6}$. Yet, focusing on the environmental and health related externalities ${ }^{7,8}$ of coal combustion will likely not be sufficient to phase out coal. Rather, it will be crucial that the coal phase out is seen as fair and that the process corresponds to political realities. Policymakers need to understand in more detail who will be affected by a transition away from coal, how these societal groups can be effectively compensated and how powerful vested interests can be counterbalanced.

\section{Expanding the notion of just transition} It is understood that a coal phase-out can only succeed if it takes into account social objectives and priorities. The necessity of a 'just transition' is widely acknowledged (Box 1). Such dialogue typically emphasizes employment creation but often fails to include considerations related to (i) regional economic development, (ii) effects of higher energy prices for consumers and energy-intensive industries and (iii) how just transition dynamics may cascade beyond individual countries?. Hence, what is needed is a just and feasible transition providing decent work and quality jobs as well as regional economic futures while at the same time limiting adverse impacts on consumers and energy-intensive industries.

Regional economic futures. While the environmental and health effects of coal are well understood, policymakers in newly industrializing countries often highlight the importance of coal for industrial development in specific regions ${ }^{10}$. Planning for alternative regional economic futures to substitute for coal requires a clearer understanding of the upstream and downstream links of coal mining and coal-fired power generation to the broader economy. Such plans could include the provision of transport and communication infrastructure, investment in higher education to attract human capital and new business opportunities, as well as the relocation of government services.

Impacts on consumers and energy-intensive industries. Renewing 


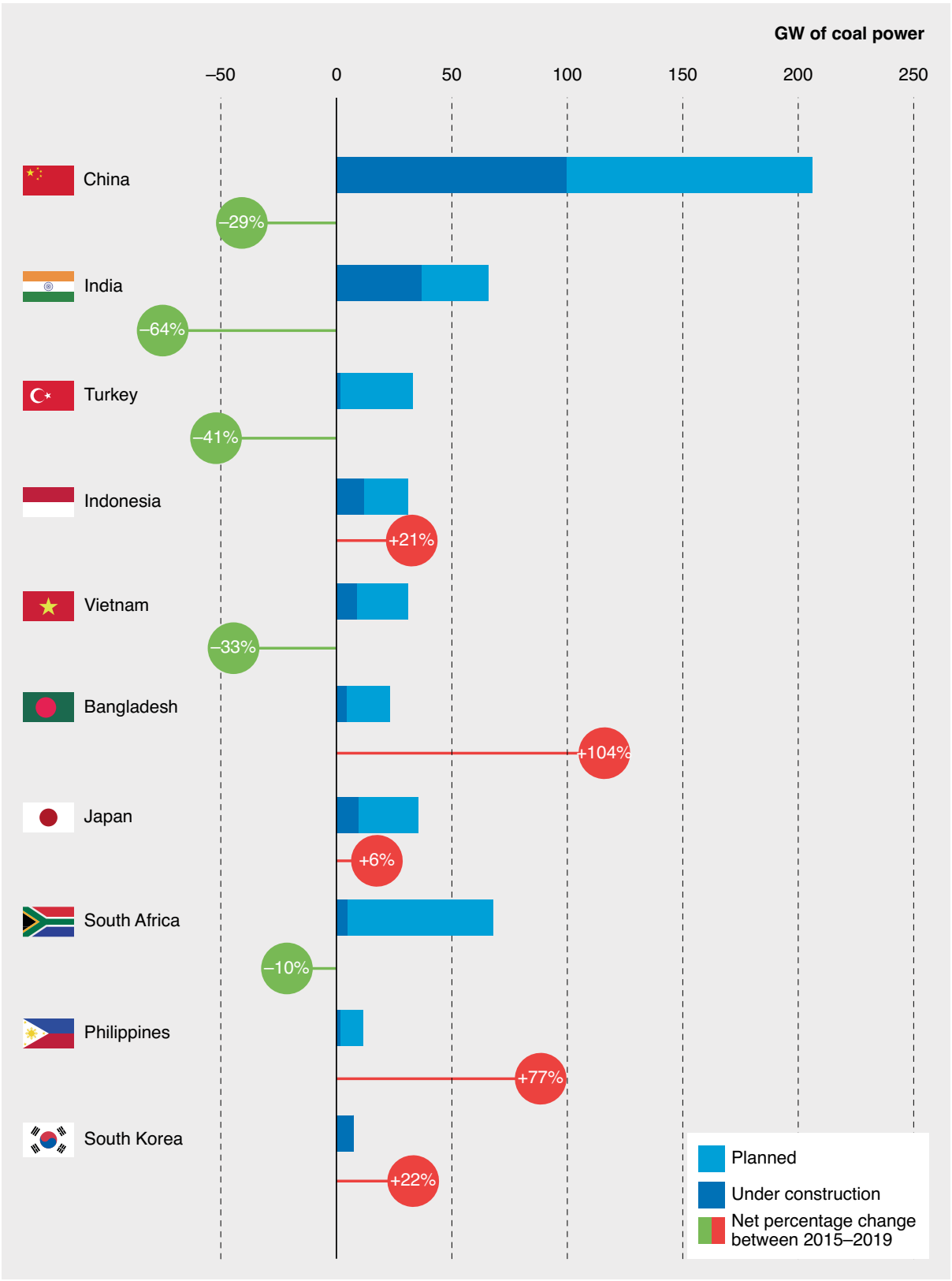

Fig. 1| The coal pipeline. Coal-fired power plants in the pipeline (planned, announced or under construction) as well as changes relative to 2015 (ref. ${ }^{19}$ ). Percentage changes denote changes in the total pipeline between 2015-2019.

energy supply systems can increase electricity system costs: for example, depreciated coal plants may produce electricity at lower costs than new alternative power generation assets. It is then a question of social equity to shield the poor from electricity price increases. This can be achieved by adjusting electricity tariffs, raising social spending or subsidizing energy efficiency, depending on the given institutional and political context.

Foregoing coal could also affect the competitiveness of industries such as steel, aluminium, chemicals and other important components of industrial strategy. This might raise the risk of 'carbon leakage'; that is, the migration of energy-intensive industries to regions with laxer climate measures, thus undermining the benefits for the climate and making coal phase-outs politically more difficult. More fine-grained projections of leakage risks in different sectors under a wide range of scenarios are required to explore which policy instruments can effectively reduce leakage. Options include coordinated implementation of emission reductions among different countries, the free allocation of permits within emissions trading schemes, border carbon adjustments, carbon contracts for difference and mechanisms of technology transfer ${ }^{11}$.

Expanding the feasibility space for phasing out coal. The coal industry typically is a powerful stakeholder with vested interests in delaying coal phase-out. Strategies to overcome the influence of vested interests might include government payments for coal power plants that are being closed. In Germany, for example, the government agreed in early 2020 on a set of measures to phase out coal by 2038 with additional costs of $€ 70-90$ billion, including $€ 4.35$ billion to operators of (lignite) coal-fired power plants that, in turn, shut down their plants early; that is, before 2030. More cost-efficient alternatives that could be assessed include accelerated carbon pricing or industry-internal schemes whereby remaining power stations pay out plants that are retiring ahead of their end of economic life $^{12}$. In addition, the interests of alternative energy producers can be leveraged to help build coalitions that create support for coal phase-out that partially offsets the opposition of those losing out ${ }^{13,14}$.

\section{A phase-out roadmap in practice}

A viable coal phase-out strategy will need to prevent new coal-fired power plants from being built. This prevents locking in long-lived assets and is usually politically easier to achieve than closing existing plants early. In many cases, expanding power supply through sources other than coal (that is, renewables or natural gas) is cost effective, even before considering the environmental and health costs of coal use. This will increasingly be the case as the cost of renewable energy technologies continues to fall. Nevertheless, there are factors that tend to favour continued investment in coal assets, including the security of supply in regions with abundant coal resources, the desire to protect jobs in the coal sector and in regional areas of coal production, dependence of public budgets on royalties from coal mining as well as political influence of owners of coal mines and power producers.

Coal phase-outs therefore require roadmaps based on a clear understanding of which plants are to be phased out when, which policies can be applied and how affected stakeholders can be included in the process.

Sequence phase-outs. The age profile of coal power plants differs greatly between 


\section{Box 1| The just transition to date}

The concept of 'just transition' goes back to the 1990s. It was coined by trade unions to support social assistance programs for workers who lost their jobs as a result of environmental policies ${ }^{20}$. In the climate policy discussion, its importance has been recognized in the preamble of the Paris Agreement, which calls for "[t]aking into account the imperatives of a just transition of the workforce and the creation of decent work and quality jobs" ${ }^{21}$, and the Solidarity and Just Transition Silesia Declaration ${ }^{22}$ adopted in 2018 at the twenty-fourth UN climate conference in Katowice, Poland. To date, there are

countries. Industrialized countries typically built up a large part of their power infrastructure before 1990, whereas India, China and many other industrializing countries ramped up coal use in the last 15 to 30 years $^{1}$ (economic logic suggests that relatively old, and typically less efficient, plants often found in developed countries should be decommissioned first). Other factors to consider are the public health impacts of associated air pollution and water use in densely populated areas. A realistic sequence of power plant closure will also need to take into account political and institutional constraints.

A nuanced understanding of the associated political barriers as well as feasible no-lose options can help to identify countries and regions where policy action in the near term is more likely than in.

\section{Choosing the right instruments.}

Coal producers and consumers need to understand the real costs of coal, including local health damages and climate consequences for the climate. Removing any existing coal subsidies would be a step to creating a level playing field for clean energy sources to compete. Some jurisdictions may want to impose an additional carbon cost on coal plants to accelerate coal phase-out. To be socially equitable and politically acceptable, a carbon price could raise funds in support of affected workers, communities and consumers. It may be usefully embedded within a broader reform to the tax system geared to assist low-income households ${ }^{15}$.

In addition, central banks and financial regulators need to include the climate and financial risks associated with coal assets in the prudential management of banks, insurers and institutional investors ${ }^{16}$. Transparent disclosure of exposure to financial risks of climate policy could a multitude of national commissions, policies, or task forces in place, including Canada, China, Czech Republic, Germany, Ghana, Indonesia, New Zealand, South Africa, Spain, USA and Vietnam. A just transition is also backed by powerful coalitions and groups such as the International Trade Union Confederation (ITUC) and the International Labour Organization (ILO). We agree with calls to expand the notion of just transitions, and to also reflect the potential negative effects of energy transitions on households and consumers, industry and regional development ${ }^{23,24}$.

provide an important motivation for investors to reallocate assets away from coal ${ }^{17}$. Financial investors increasingly decline to invest in coal-based assets already, because they are seen as high risk ${ }^{18}$.

\section{Stakeholder involvement and}

communication. Efforts to phase out coal will only succeed if stakeholders are involved early on in the decision process to ensure democratic legitimacy. This is particularly important during times in which populist parties increasingly depict climate change mitigation as a project undertaken by the political elite against the interests of the broader population, and where well-founded concerns about economic prosperity dominate public discourse.

Different forms of public deliberation, such as stakeholder dialogues, just transition commissions and citizen assemblies, reflect public opinion and could be apt to further agreement between different interests. This raises the question of how participants are selected, in which form and frequency discussions take place, how scientific knowledge is used as an input and how the results of public deliberation are used by policymakers. Policymakers could adapt their communication strategies on coal phase-out for different audiences that highlight the key benefits that align with individual concerns; for instance, emphasizing the importance of coal phase-out for climate change mitigation for one social group and the more localized benefits of reduced air pollution for others.

\section{How to phase out coal}

To achieve internationally agreed climate targets, the world will need to phase out coal rapidly and immediately. This may be politically even more difficult in the altered political and economic landscape after the coronavirus pandemic. Roadmaps for coal phase-out, smart use of a combination of policy instruments and effective integration of powerful stakeholders into the process are key to success.

\section{Michael Jakob(iD) ${ }^{1 \times}$ \\ Jan Christoph Steckel (D) 1,2凶, Frank Jotzo (D) ${ }^{3}$ Benjamin K. Sovacool (D) ${ }^{4}$, Laura Cornelsen ${ }^{5}$, Rohit Chandra6, Ottmar Edenhofer (D) 1,2,7, Chris Holden ${ }^{8}$, Andreas Löschel(iD) 9,10, Ted Nace ${ }^{11}$, Nick Robins ${ }^{12}$, Jens Suedekum ${ }^{13}$ and Johannes Urpelainen ${ }^{14}$ \\ ${ }^{1}$ Mercator Research Institute on Global Commons and Climate Change, Berlin, Germany. ${ }^{2}$ Potsdam Institute for Climate Change Impact Research, Potsdam, Germany. ${ }^{3}$ Crawford School of Public Policy, Australian National University, Canberra, Australian Capital Territory, Australia. ${ }^{4}$ Science Policy Research Unit, University of Sussex, Sussex, UK. ${ }^{5}$ Faculty of Public Health and Policy, London School of Hygiene \& Tropical Medicine, London, UK. ${ }^{6}$ Center for Policy Research, New Delhi, India. ${ }^{7}$ Department of Economics of Climate Change, Technische Universität Berlin, Berlin, Germany. ${ }^{8}$ Department of Social Policy and Social Work, University of York, York, UK. 'School of Business and Economics, University of Münster, Münster, Germany. ${ }^{10}$ Fraunhofer Center for Economics of Materials, Halle, Germany. ${ }^{11}$ Global Energy Monitor, San Francisco, CA, USA. ${ }^{12}$ Grantham Research Institute, London School of Economics and Political Science (LSE), London, UK. ${ }^{13}$ Düsseldorf Institute for Competition Economics (DICE), Heinrich-Heine-University, Düsseldorf, Germany. ${ }^{14}$ Johns Hopkins School of Advanced International Studies, Washington D.C., WA, USA. \\ $凶_{e-m a i l: j a k o b @ m c c-b e r l i n . n e t ;}$ steckel@mcc-berlin.net}

Published online: 27 July 2020

https://doi.org/10.1038/s41558-020-0866-1

References

1. Edenhofer, O., Steckel, J. C., Jakob, M. \& Bertram, C. Environ. Res. Lett. 13, 024019 (2018).

2. Global Coal Mining Industry - Market Research Report (IBISWorld, 2019); https://www.ibisworld.com/global/ market-research-reports/global-coal-mining-industry/

3. Thurber, M. C. \& Morse, R. K. in The Global Coal Market (eds Thurber, M. C. \& Morse, R. K.) 3-34 (Cambridge Univ. Press, 2015).

4. Jewell, J., Vinichenko, V., Nacke, L. \& Cherp, A. Nat. Clim. Change 9, 592-597 (2019).

5. Steckel, J. C., Hilaire, J., Jakob, M. \& Edenhofer, O. Nat. Clim. Change 10, 83-88 (2020).

6. Luderer, G. et al. Nat. Clim. Change 8, 626-633 (2018).

7. Li, M., Zhang, D., Li, C.-T., Selin, N. E. \& Karplus, V. J. Environ. Res. Lett. 14, 084006 (2019).

8. Muller, N. Z., Mendelsohn, R. \& Nordhaus, W. Am. Econ. Rev. 101, 1649-1675 (2011).

9. Sovacool, B. K., Hook, A., Martiskainen, M. \& Baker, L. Glob. Environ. Chang. 58, 101958 (2019).

10. Kalkuhl, M. et al. Nat. Energy 4, 897-900 (2019).

11. Jakob, M., Steckel, J. C. \& Edenhofer, O. Annu. Rev. Resour. Econ. 6, 297-318 (2014).

12. Jotzo, F. \& Mazouz, S. B. E. J. Econ. Anal. 48, 71-81 (2015).

13. Kim, S. E., Urpelainen, J. \& Yang, J. J. Public Policy 36, 251-275 (2016).

14. Hess, D. J. Energy Res. Soc. Sci. 57, 101246 (2019).

15. Klenert, D. et al. Nat. Clim. Change 8, 669-677 (2018). 
16. First Meeting of the Central Banks and Supervisors Network for Greening the Financial System (NGFS) on January 24th in Paris. Central Banks and Supervisors Network for Greening the Financial System (26 January 2018); https://www.ngfs.net/en/communiquede-presse/first-meeting-central-banks-and-supervisors-networkgreening-financial-system-ngfs-january-24th-0

17. Guidelines on Reporting Climate-related Information (European Commission, 2019); https://ec.europa.eu/finance/ docs/policy/190618-climate-related-information-reportingguidelines_en.pdf
18. The Investor Agenda. 2018 Global Investor Statement to Governments on Climate Change (COP24 Presidency Office, Ministry of the Environment, 2018).

19. Global Coal Plant Tracker (Global Energy Monitor, 2020).

20. Smith, S. Just Transition: A Report for the OECD (OECD Publishing, 2017); https://www.oecd.org/ environment/cc/g20-climate/collapsecontents/ Just-Transition-Centre-report-just-transition.pdf 21. Adoption of the Paris Agreement FCCC/CP/2015/L.9/Rev.1 (UNFCCC, 2015)
22. Solidarity and Just Transition Silesia Declaration (COP24 Presidency Office, Ministry of the Environment, 2018); https://cop24.gov.pl/fileadmin/user_upload/ Solidarity_and_Just_Transition_Silesia_Declaration_ 2_.pdf

23. Carley, S. \& Konisky, D. M. Nat. Energy https://doi.org/10.1038/ 441560-020-0641-6 (2020).

24. Jenkins, K. E. H., Sovacool, B. K., Błachowicz, A. \& Lauer, A. Geoforum (in the press); https://doi.org/10.1016/j.geoforum. 2020.05.012

\section{nature} communications

Publishing high-quality open access research from across all areas of the natural sciences.
Submit your research and benefit from a fast decision process, full open access, CC BY licensing as standard, the \#3 most-cited* multidisciplinary open access journal in the world and 3 million monthly page views on journal site.

*Clarivate Analytics, 2019 